\title{
HEAT TREATMENT OF TI-6AL-4V PRODUCED BY LASERCUSING\#
}

\author{
T. Becker ${ }^{1 *}$, M. van Rooyen ${ }^{2} \&$ D. Dimitrov ${ }^{3}$ \\ 1,2Department of Mechanical Engineering \\ University of Stellenbosch, South Africa \\ 1tbecker@sun.ac.za \\ ${ }^{3}$ Department of Industrial Engineering \\ University of Stellenbosch, South Africa
}

\begin{abstract}
LaserCUSING $®$ is a selective laser melting (SLM) process that is capable of manufacturing parts by melting powder with heat input from a laser beam. LaserCUSING demonstrates potential for producing the intricate geometries specifically required for biomedical implants and aerospace applications. One main limitation to this form of rapid prototyping is the lack of published studies on the material performance of the resulting material. Studies of the material's performance are often complicated by dependence on several factors, including starting powder properties, laser parameters, and post-processing heat treatments. This study aims to investigate the mechanical properties of LaserCUSINGproduced Ti-6Al-4V and its performance relative to the conventional wrought counterpart. A combination of conventional and LaserCUSING-tailored heat treatments is performed. The resulting microstructures are studied and linked to the properties obtained from hardness tests. The findings highlight that LaserCused Ti-6Al-4V is competitive with traditional materials, provided that optimal parameters are chosen and parts are subject to tailored post-processing. In the as-built condition, LaserCused Ti-6Al-4V displays superior strength and hardness as a result of a martensitic microstructure, and a poorer performance in ductility. However, the material performance can be improved using tailored heat treatments. Careful consideration must be given to suitable post-processing before application in critical components in the aerospace or biomedical industry can occur.
\end{abstract}

\section{OPSOMMING}

LaserCUSING ${ }^{\circledR}$ is ' $n$ selektiewe lasersmeltproses met die vermoë om onderdele te vervaardig deur die smelt van poeier met hitte inset van ' $n$ laserstraal. LaserCUSING toon die potensiaal om ingewikkelde geometrieë benodig vir biomediese implantate en lugvaart toepassings, te produseer. Een van die hoof beperkings tot hierdie vorm van blits prototipering is die tekort aan gepubliseerde studies oor die materiaaleienskappe van die gevolglike materiaal. Studies van die materiaaleienskappe is dikwels verder gekompliseer as gevolg van die invloed van verskeie faktore, soos die aanvanklike poeier eienskappe, die laser parameters en hittebehandelings na die lasersmeltproses. Hierdie studie beoog om die meganiese eienskappe van Ti-6Al-4V wat met LaserCUSING geproduseer is, en die vertoning daarvan relatief tot ' $n$ konvensionele bewerkte eweknie, te ondersoek. ' $n$ Kombinasie van konvensionele en aangepaste hittebehandelings is toegepas. Die resulterende mikrostrukture is ondersoek en verwantskappe tot die resultate van hardheidstoetse is gevind. Die resultate toon dat die Ti-6Al-4V met tradisionele materiale kan kompeteer mits optimale parameters vooraf gekies word en dat onderdele aangepaste hittebehandelings ondergaan. Die Ti-6Al-4V toon beter sterkte en hardheid, maar het swakker smeebaarheid. Noukeurige oorweging vir verwerking na die lasersmelt is nodig voor die toepassing daarvan op kritiese komponente.

This article is an extension of a paper presented at the $15^{\text {th }}$ Annual International RAPDASA conference held in Stellenbosch, South Africa in November 2014.

Corresponding author 
The recent demand from industry to gain greater control of customised part manufacture using the combined strengths of computer aided design (CAD) and 3D printing methods has focused interest on additive manufacturing (AM) techniques. These layer-wise manufacturing methods support a market niche for components with shorter production times and intricate geometry details [1]. Although applications were historically confined to the production of prototypes, modern methods extend to the manufacturing of tooling inserts, biomedical implants, mass-customised consumer products, aerospace components, and artwork [1-7]. Among the AM methods, selective laser melting (SLM) dominates applications in the industrial and academic sectors [3].

Compared with conventional fabrication routes, SLM offers a range of benefits. The complete melting of the metallic powder particles results in a near-100 per cent dense product without the need for component-specific tooling [3]. This results in reduced production time and maximises material utilisation. Additionally, the layer-by-layer control provides geometrical freedom, and allows the designer to focus more on the functionality of the part than on its manufacturability [2].

One example of a commercial SLM method is LaserCUSING $\circledast$ by CONCEPT Laser GmbH. The process uses a stochastic exposure scheme based on the 'island principle'. Each powder layer is divided into 'islands' that are laser-scanned, based on a random distribution. It is claimed that this strategy reduces the accumulation of residual stresses caused by steep temperature gradients [8]. The starting material consists of single-component metallic powders generated by an atomisation process, and includes steel, aluminium, nickel-based, titanium, bronze, and precious-metal alloys.

Possibly the most prominent candidate material for demonstrating the industrial potential of LaserCUSING manufactured components is the titanium alloy Ti-6Al-4V. This alloy has the majority market share of titanium products, and is known for its high strength-to-density ratios, corrosion resistance, and relatively high temperature capabilities $[9,10]$. The good biocompatibility properties of Ti-6Al-4V, combined with the geometrical flexibility of LaserCUSING, makes the alloy an attractive option for creating customised medical implants [11]. The ability of SLM techniques to fabricate intricate cooling channels also extends the material's scope of applications to aero-engine turbine blades [12].

Despite the successes of LaserCUSING ${ }^{\circledR}$ and other SLM methods, a few problems are frequently encountered. One concern is the introduction of residual stresses due to the localised thermal input from the laser. These stresses, which can exceed the yield strength of the material, result from the temperature gradient mechanism in which previously solidified layers hinder the thermal expansion of the newly-formed areas [12]. Residual stresses have been attributed to the degradation of mechanical properties, part distortion, and micro-crack formation [12,14,15]. Furthermore, 100 per cent density is often difficult to achieve by SLM methods due to the absence of mechanical pressure (as in conventional procedures) and the difficulty of laying an even powder layer [14]. The porosity in the LaserCUSING manufactured part has a direct effect on the resulting mechanical properties. For instance, micro-flaws and voids serve as stress raisers for crack initiation, and vastly reduce fatigue performance $[13,17]$.

Another concern with LaserCUSING processed Ti-6Al-4V is how the as-built mechanical properties compare with those of wrought forms. In particular, the fast cooling rates and layer-wise building in the LaserCUSING process result in a fine, non-equilibrium phase and anisotropic behaviour [16-20]. This martensitic microstructure manifests in high hardness and high strength/low ductility material behaviour, requiring the use of heat treatments to obtain a balance of properties similar to those of the bulk materials. Bracken et al. [20] revealed that heat treatments require tailoring to the as-built starting microstructure in 
order to improve properties. So standard heat treatments such as mill, duplex, and beta annealing do not optimise LaserCUSING processed material performance.

The above argument reveals that the industrial implementation of LaserCUSING Ti-6Al-4V products pivots on the characterisation of its as-built material behaviour, optimisation of processing parameters, and successful application of remedial post-processing. In this study, LaserCUSING processed Ti-6Al-4V is subjected to hardness evaluation, microstructural analysis, and density investigations. Focus is placed on the combination of machine parameters and heat treatments that will optimise material behaviour while minimising residual stresses and porosity defects.

\section{EXPERIMENTAL METHODOLOGY}

This study highlights the collective findings of Van Rooyen [21] and Khan [22] specifically related to the LaserCUSING process. The investigated material properties encompass the density, hardness, and microstructural detail. The effects of both SLM-tailored heat treatments are studied, together with the process parameter-dependence of the material porosity levels.

\subsection{Specimen fabrication}

The specimen base material selected was extra-low interstitial (ELI) Ti-6Al-4V powder, designated as CL 41 It (ELI). The Ti-6Al-4V ELI grade is a higher-purity version of Ti-6Al-4V, with lower amounts of iron impurities and carbon and oxygen interstitials [9]. The lower oxygen content of this material makes it more suitable for fracture-critical aerospace, medical, and cryogenic applications [23]. The powder particles, produced by gas atomisation, range from 38 to $45 \mu \mathrm{m}$ in size.

All samples were produced on an M2 LaserCUSING machine in the Rapid Product Development Laboratory at the University of Stellenbosch. The machine is equipped with a 200W continuous wave fibre laser with a variable laser spot diameter. During fabrication, the build chamber is flushed with an argon atmosphere to prevent the oxidation of the titanium parts. The samples were built with $100 \mathrm{~W}$ laser power, $30 \mu \mathrm{m}$ powder layer thickness, and a $150 \mu \mathrm{m}$ focus diameter. The density samples were printed in cylindrical form (height $25 \mathrm{~mm}$, diameter $10 \mathrm{~mm}$ ), with the axis parallel to the $Z$ direction according to the ISO/ASTM52921-13 orientation designations.

In order to investigate the effect of process settings on material density, three laser parameters are varied. Hatch spacing refers to the distance between adjacent laser vectors, and has been reported to influence the quality of the resulting component surface [24]. Laser scan speed dominates to a great extent the laser-powder interaction time, which in turn affects the stability of the molten powder paths [25]. The build pattern refers to whether the 'islands' are created after a single exposure (the standard method) or a double exposure known as a remelt. Multiple exposures have been found to improve component density and surface quality [26]. Hatch spacing of 50, 70 and 90 per cent of the focus diameter, scan speeds of 600,800 and $1000 \mathrm{~mm} / \mathrm{s}$, and both exposure strategies were examined.

\subsection{Heat treatment}

It has previously been reported that SLM-produced Ti-6Al-4V comprises martensitic microstructures with evidence of acicular $a$ ' phases and no $B$ phase $[13,18,20,16]$. Given that this starting microstructure is vastly different from conventional forms, standard heat treatments will not necessarily provide the desired result. Instead, tailoring of heat processing parameters such as holding time, maximum temperature, and cooling rate can achieve a better balance of properties for LaserCUSING processed materials [20].

In this study, tailored heat treatments were conducted in order to observe the effect on the microstructure of the LaserCUSING material. The heat treatments were conducted in a 
vacuum furnace in order to prevent oxidation of Ti-6Al-4V above $427^{\circ} \mathrm{C}$ [10]. A standard mill anneal is shown in Figure 1a for the purpose of comparison [12].

Tailored heat treatment A: This treatment combines the standard beta anneal process with a moderate furnace cooling, and occurs in two stages. The aim of the first recrystallisation step is the decomposition of the martensitic structure and tailoring of the grain size and phase distribution, whereas the second step serves as a stress relief treatment. A moderate cooling allows for coarsening of the microstructure. These steps are shown in Figure 1a.

Tailored heat treatment B: Similar to Treatment A, this process occurs in two stages, with the main aim of treating below the beta-transus for an extended period. The treatment stems from the conventional duplex anneal. The difference is that the first cooling is not taken down to room temperature, and moderate furnace cooling is employed for grain growth. These steps are shown in Figure $1 \mathrm{a}$.

Tailored heat treatment $\mathrm{C}$ : The purpose of this treatment is to combine high strength with good ductility. The first stage is aimed at enhancing the ductility by heating close to the beta-transus for a coarsening of the microstructure. This is followed by a slow cool to enable further globularisation of the alpha phase. The second stage, a low temperature anneal, is aimed at enhancing the material strength through the precipitation of acicular alpha between the globularised plates. Excessive grain growth (associated with weaker tensile strength [9]) is prevented by air cooling in a muffle furnace. These steps are shown in Figure 1b.

Thermohydrogen processing: An alternative to industrial heat treatments of Ti-6Al-4V is thermohydrogen processing (THP), as shown in Figure 1c. This involves a heat treatment in which specimens are alloyed with $20 \pm 3$ atomic per cent hydrogen. The hydrogen lowers the beta-transus temperature, and allows the metal to recrystallise at lower temperatures, resulting in refined beta grains [27]. The treatment in this study focused on the martensite decomposition form of THP (THP-MD), but excluded hot deformation steps. Stages 1 and 4 take place in a vacuum furnace, whereas stages 2 and 3 are conducted in a muffle furnace.

\subsection{Microstructural evaluation}

Disks were cut in the radial and axial directions in order to study the anisotropic microstructural behaviour typical of SLM-made parts [17-20]. The radial and axial viewing directions respectively refer to the XY plane and Z directions, according to ISO/ASTM5292113. Once cut and mounted, specimens were ground, polished, and etched with Kroll's reagent. Micrographs were produced using the Olympus GX51 optical microscope.

\subsection{Density and flaw investigations}

Specimen density was measured using the water displacement method of ASTM B311-93. A precise $40 \mathrm{SM}-200 \mathrm{~A}$ analytical scale with a sensitivity of $0.0001 \mathrm{~g}$ was used to calculate a relative density (relative to $4.42 \mathrm{~g} / \mathrm{cm}^{3}$ ). Three specimens for each laser speed, hatch spacing, and hatch pattern combination were tested, leading to a total of 54 cylinders. The cylinders that gave rise to the most notable density values were then selected for an X-ray investigation using a CT (Computed Tomography) scanner. The scanner used was a General Electric Phoenix V|tome|x L 240 equipped with a $240 \mathrm{kV} / 320 \mathrm{~W}$ micro focus X-ray filament with a resolution of 3 am (for a scan volume of $5 \times 5 \mathrm{~mm}$ ).

\section{EXPERIMENTAL RESULTS}

\subsection{Microstructure}

The non-heat-treated structure is shown in Figure 2a. At a low magnification, a checkerboard pattern is seen in the axial viewing direction. A needle-like structure signifies the presence of a fully acicular a' martensitic microstructure that results from the high cooling rates during the LaserCUSING process. Large columnar grains oriented parallel to 
layer growth are seen in the radial direction in Figure 2b. Vrancken et al. [20] have identified these grains as epitaxial solidified prior beta grains.
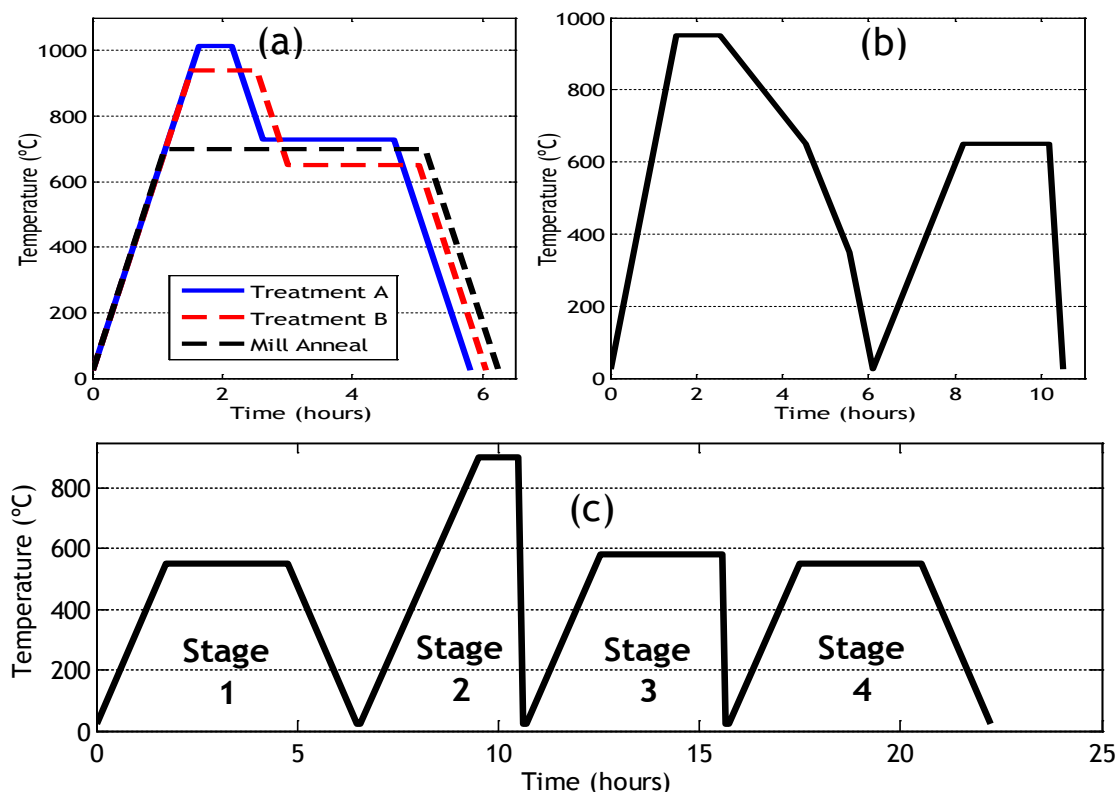

Figure 1: Heat treatment plan for the tailored heat treatments $A$ and $B(a)$, heat treatment $C$ (b), and THP-MD treatment (c)

Table 1: Summary of tailored heat treatments

\begin{tabular}{|c|c|c|c|c|}
\hline \multirow[t]{2}{*}{ Treatment } & \multirow[t]{2}{*}{$\begin{array}{l}\text { Holding temp. } \\
\left({ }^{\circ} \mathrm{C}\right)\end{array}$} & \multirow{2}{*}{$\begin{array}{l}\text { Holding } \\
\text { time } \\
\text { (hrs.) }\end{array}$} & $\begin{array}{c}\text { Heating } \\
\text { rate }\end{array}$ & Cooling rate \\
\hline & & & \multicolumn{2}{|r|}{$\left({ }^{\circ} \mathrm{C} / \mathrm{min}\right)$} \\
\hline \multirow[t]{2}{*}{ A } & $\begin{array}{l}1015 \text { (above } \\
\text { beta-transus) }\end{array}$ & 0.5 & 10 & 10 (furnace cool) \\
\hline & 730 & 2 & & 10 (furnace cool) to room temp. \\
\hline \multirow[t]{2}{*}{ B } & $\begin{array}{l}940 \text { (below } \\
\text { beta-transus) }\end{array}$ & 1 & 10 & 10 (furnace cool) \\
\hline & 650 & 2 & & 10 (furnace cool) to room temp. \\
\hline \multirow{2}{*}{ C } & $\begin{array}{l}950 \text { (below } \\
\text { beta-transus) }\end{array}$ & 1 & 10 & $\begin{array}{l}2.5 \mathrm{cool} \text { to } 650^{\circ} \mathrm{C}, 5 \text { cool to } 350^{\circ} \mathrm{C} \\
\text { (furnace cool), } 10 \text { to room temp. }\end{array}$ \\
\hline & 650 & 2 & $\begin{array}{l}5 \text { (muffle } \\
\text { furnace) }\end{array}$ & Air cool to room temp. \\
\hline Mill Anneal [12] & $700-780$ & $1-8$ & 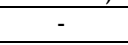 & Air cool \\
\hline \multicolumn{5}{|c|}{ Thermo hydrogen processing (THP) } \\
\hline $\begin{array}{c}\text { Stage 1: } \\
\text { hydrogen gas }\end{array}$ & $\begin{array}{l}\text { Hydrogenation } \\
\text { at } 550\end{array}$ & 3 & \multirow{4}{*}{5} & 5 (furnace cool) to room temp. \\
\hline Stage 2 & $\begin{array}{c}\text { Solution } \\
\text { treating and } \\
\text { ageing at } 900\end{array}$ & 1 & & Water quench \\
\hline Stage 3 & Ageing at 580 & 3 & & Water quench \\
\hline $\begin{array}{l}\text { Stage 4: } \\
\text { vacuum }\end{array}$ & $\begin{array}{l}\text { Dehydrogena- } \\
\text { tion at } 550\end{array}$ & 3 & & 5 (furnace cool) to room temp. \\
\hline
\end{tabular}

The tailored heat treatment A resulted in a bimodal structure dotted with regions of semiequated beta grains and lamellar alpha and beta, as shown in Figure 2c. Large acicular alpha regions with plates of $50 \mu \mathrm{m}$ were observed, and were expected for a moderate furnace cooling rate [20]. All traces of the columnar $B$ grains have been erased by the supertransus treatment, as shown in Figure $2 \mathrm{~d}$. Heat treatment $\mathrm{B}$ caused the formation of fine alpha needles within lamellar regions of the alpha and the beta phase. This structure, seen in Figure 2e, forms as a result of the nucleation along the a' boundaries of alpha 
phases (which are present in lower volume fractions at the high temperature end of the $a+B$ region). Expulsion of the vanadium atoms then results in the formation of beta along the alpha phase boundaries [20]. The columnar grains become more visible due to the formation of grain boundary alpha (Figure $2 \mathrm{f}$ ). Heat treatment $\mathrm{C}$ produced a more equiaxed microstructure in the axial orientation, shown in Figure $2 \mathrm{~g}$. The micrograph in Figure $2 \mathrm{~h}$ reveals a fine needle-like structure within lean columnar beta grains for the radial direction. The lean grains are due to the slow cooling of the first stage, whereas the faster air cool of Stage 2 results in the fine structure. Evidence of martensite was found in the radial micrographs due to the contamination of the ceramic slurry that resulted in uneven cooling rates. The THP treatment produced large acicular beta grains in the axial direction, as shown in Figure $2 \mathrm{i}$. The development of large grains within a semi-equiaxed microstructure in the radial viewing orientation can be noted in Figure $2 \mathrm{j}$. This provided evidence that the treatment decomposes the former columnar grains into more acicular structures. Quenching from the $\alpha+B$ phase region is responsible for this structure, as the primary lamellar alpha phase is retained. As found by Vilane [27], a large concentration of fine alpha needles is located in the prior beta grains.

\subsection{Density evaluation}

The variation in the density for combinations of laser speed, hatch spacing, and hatch pattern is shown in Figure 3. For each parameter set, the measured density is normalised to the theoretical density of wrought Ti-6Al-4V of $4.43 \mathrm{~g} / \mathrm{cm}^{3}$ [23]. The comparison between the CT scan and the water displacement results is summarised in Table 2. The pore distributions for the three specimens are shown in Figure 4.

Mean density values range from 95.2 per cent to 99.6 per cent for the single hatch pattern, and between 97.2 per cent and 99.8 per cent for the remelt strategy. As indicated in Figure $3 a$, calculated 100 per cent relative density values are observed for the $0.5 \mathrm{~d}$ spacing and $1000 \mathrm{~mm} / \mathrm{s}$ speed. The high scan speed minimises heat transfer and resultant splattering, whereas the smaller spacing allows for better overlap of scanning tracks [25]. The remelt build pattern resulted in an average relative density that is 0.32 per cent higher than that produced by the single counterpart pattern. Studies conducted by Yasa \& Kruth [28] attributed this to the improvement in surface roughness. The smaller valleys and peaks in the solidified layers allow an even distribution of powder and more uniform penetration of heat.

As seen in Figure 4a for the low density sample, the pores tend to align with the layer build direction. However, a second pattern is shown where the pore alignment is at a slope to the build direction. This pattern is more clearly seen in the 3D representation of the pore distribution (coloured blue). Studies conducted by Kruth et al. [14] observed this sloping alignment, and proposed that it could be attributed to a scan spacing that is larger than the molten track width. Furthermore, the axial view showed a distinct cross hatch pattern with the spacing between lines in the order of $140 \mu \mathrm{m}$. This distance corresponds to the $0.9 \mathrm{~d}$ hatch spacing parameter.

\subsection{Hardness evaluation}

The mean hardness of at least six indentations for the different heat treatments and orientations is given in Table 3. High hardness values were observed for the as-built specimens, and are characteristic of the martensitic microstructure [12]. The course microstructure of the samples exposed to treatment A resulted in the lowest hardness values, possibly indicating a low strength-high ductility material property combination.

Table 2: Comparison between water displacement and CT scan density results

\begin{tabular}{|l|l|c|}
\hline \multicolumn{1}{|c|}{ Parameter combination } & Water displacement & CT scan \\
\hline $0.9 \mathrm{~d}, 1000 \mathrm{~mm} / \mathrm{s}$, single & $95.19 \pm 0.04 \%$ & $94.60 \pm 0.25 \%$ \\
\hline $0.7 \mathrm{~d}, 600 \mathrm{~mm} / \mathrm{s}$, remelt & $98.98 \pm 0.15 \%$ & $99.55 \pm 0.25 \%$ \\
\hline $0.7 \mathrm{~d}, 600 \mathrm{~mm} / \mathrm{s}$, single & $98.50 \pm 0.15 \%$ & $98.18 \pm 0.25 \%$ \\
\hline
\end{tabular}




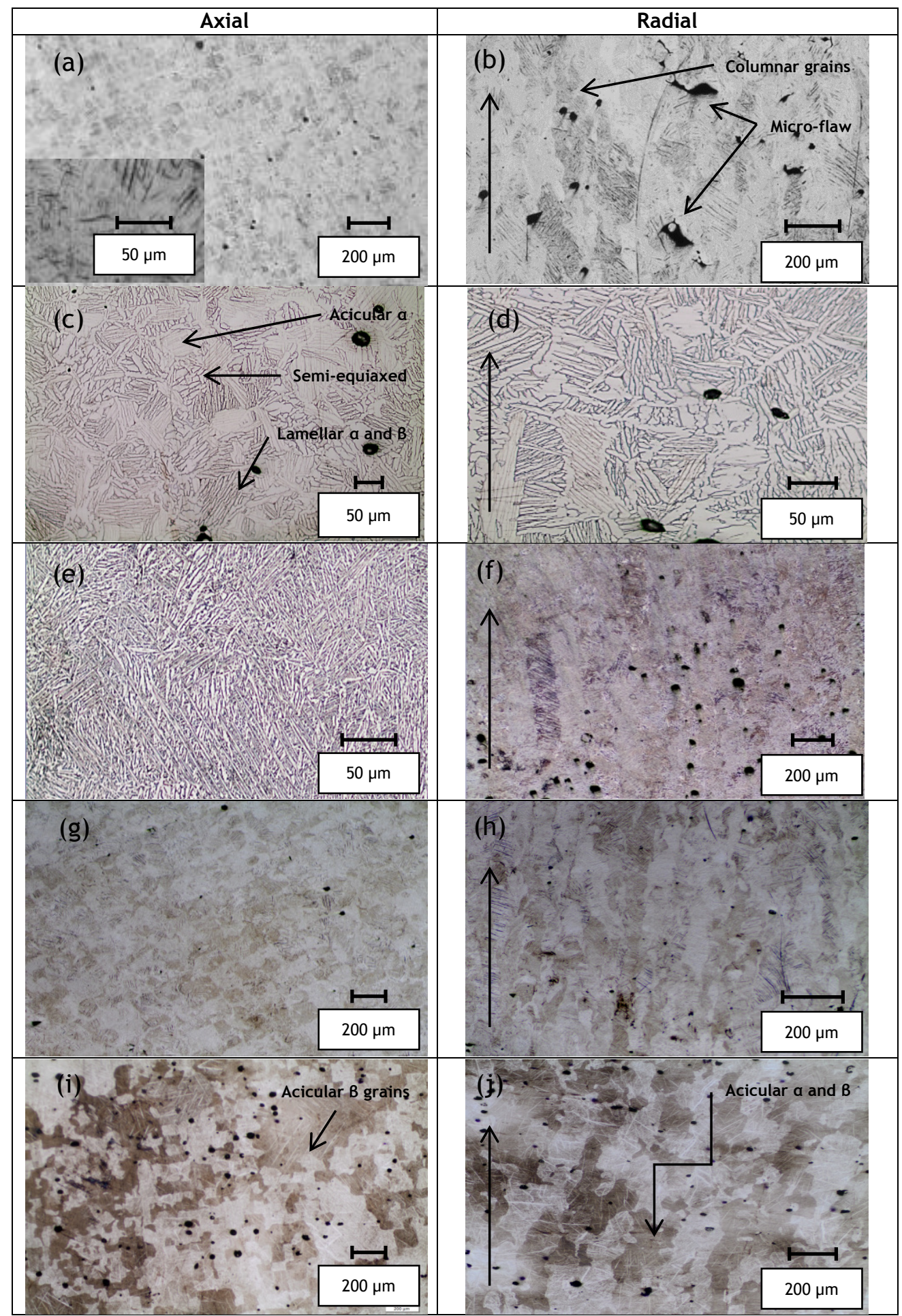

Figure 2: Micrographs for as-built condition (a) and (b), heat treatment A (c) and (d), heat treatment $B(e)$ and $(f)$, heat treatment $C(g)$ and $(h)$, and THP treatment (i) and $(j)$. The vertical arrow indicates the build $(Z)$ direction. 

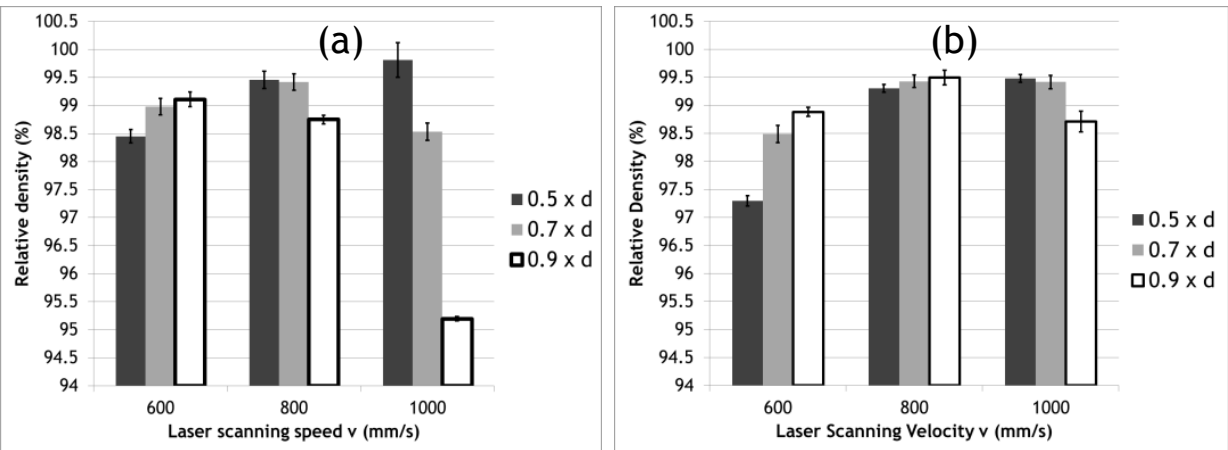

Figure 3: Density results as a function of laser parameters for the remelt exposure (a) and the single exposure (b)
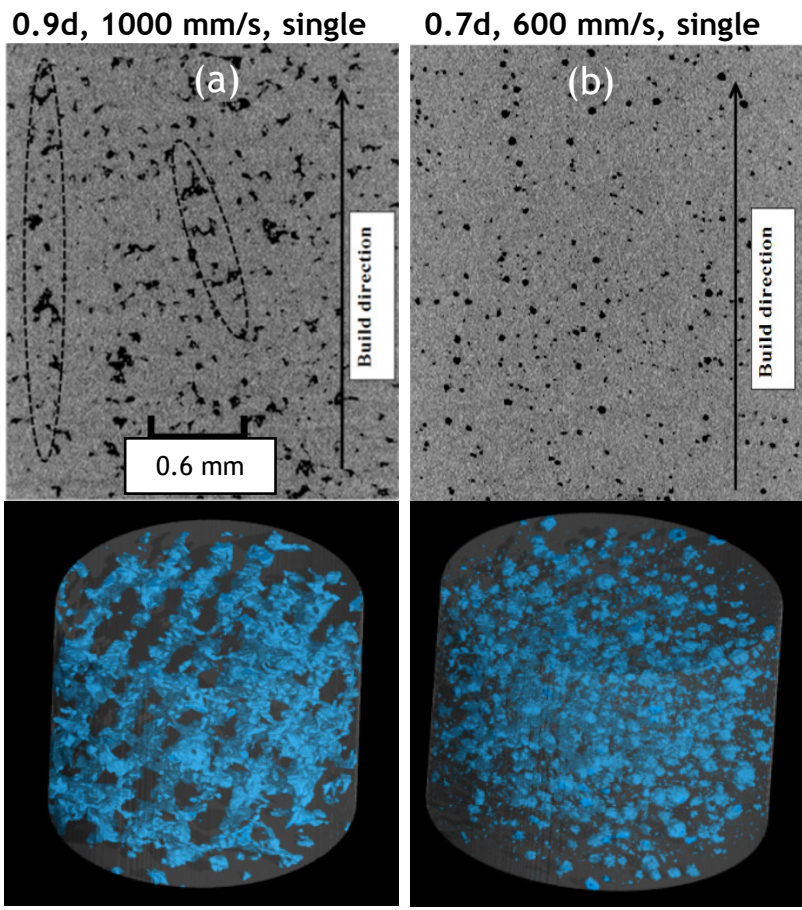

$0.7 \mathrm{~d}, 600 \mathrm{~mm} / \mathrm{s}$, remelt

$\longmapsto 0.3 \mathrm{~mm}$

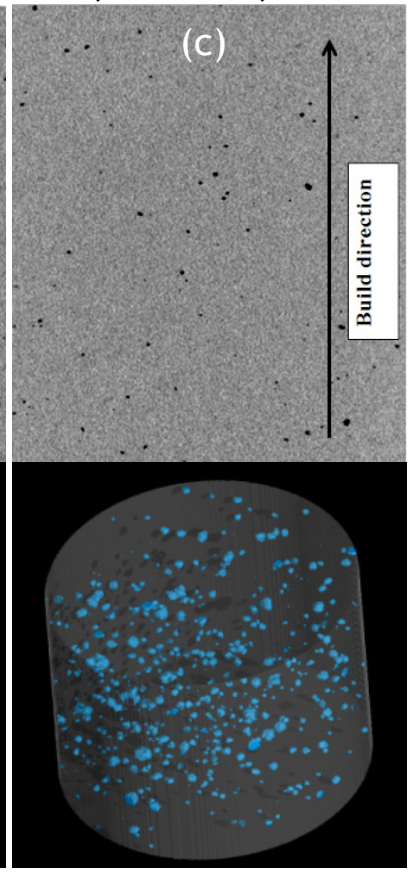

Figure 4: CT scans showing a radial view (top) and 3D representation (bottom) for the low density specimen (a), the standard single parameter combination (b), and the remelt combination (c)

Treatment $B$ and the THP process best matched the hardness values reported for wrought counterparts $\left(349 \mathrm{HV}_{10}\right)$, indicating a suitable balance of properties. However, uneven cooling during treatment $\mathrm{C}$ resulted in fine alpha needles as well as an equiaxed structure, causing a large variation of hardness values $\left(326-384 \mathrm{HV}_{10}\right)$.

\section{DISCUSSION}

The tailored heat treatments were selected based on previous SLM post-processing studies [20], and were aimed at the decomposition of the starting martensitic microstructure into the more equiaxed microstructure of conventional forms of the material. Refinement to such a microstructure will enhance the applicability of LaserCused Ti-6Al-4V ELI parts with respect to a favourable balance of quasi-static properties. Although the most drastic change 
Table 3: Summary of Vickers hardness measurements

\begin{tabular}{|c|c|c|c|c|c|}
\hline Heat treatment & Specimen & Axial $\left(\mathbf{H V}_{\mathbf{1 0}}\right)$ & $\begin{array}{c}\text { Standard } \\
\text { deviation }\end{array}$ & Radial $\mathbf{( H V _ { 1 0 } )}$ & $\begin{array}{c}\text { Standard } \\
\text { deviation }\end{array}$ \\
\hline $\begin{array}{c}\text { As-built (0.7d, 600 } \\
\text { mm/s, single) }\end{array}$ & 1 & 367 & 5 & 354 & 6 \\
\hline \multirow{2}{*}{ Tailored A } & 1 & 322 & 5 & 300 & 11 \\
\cline { 2 - 6 } & 2 & 319 & 3 & 293 & 11 \\
\hline \multirow{2}{*}{ Tailored B } & 1 & 339 & 8 & 333 & 5 \\
\cline { 2 - 6 } & 2 & 336 & 6 & 330 & 4 \\
\cline { 2 - 6 } Tailored C & 1 & 357 & 6 & 351 & 6 \\
\cline { 2 - 6 } & 3 & 364 & 10 & 384 & 8 \\
\cline { 2 - 6 } & 1 & 326 & 6 & 330 & 6 \\
\hline \multirow{2}{*}{ THP } & 2 & 333 & 6 & 332 & 6 \\
\hline Wrought [10] & - & 349 & - & 349 & - \\
\hline
\end{tabular}

in microstructure occurred after the heat treatment above the beta-transus (treatment $A$ ), the SLM-tailored heat treatment below the beta-transus (treatment $B$ ) produced a hardness similar to wrought $\mathrm{TI}-6 \mathrm{Al}-4 \mathrm{~V}$. The literature reveals that the expected tensile strength and ductility for SLM TI-6Al-4V, when subjected to treatment B, is about $948 \mathrm{MPa}$ and $13.6 \%$ respectively [20]. This reveals a good compromise between properties. Furthermore, THP treatments did not completely refine the microstructure to fine equiaxed grains, due to the exclusion of the hot deformation and recrystallisation steps to shorten the processing time.

Residual stresses cause scatter in tensile and crack growth values in the as-built condition, but are readily alleviated by up to 97 per cent through a standard recrystallisation annealing [12]. Leuders et al. [17] have shown that porosity reduction through a hot isostatic pressing did not markedly improve tensile values over regular heat treatments. Furthermore, the selection of appropriate hatch spacing, patterns, and scan speeds that result in both stable melt pools and sufficient melting can be easily done to achieve nearfull density of components.

Areas of concern for LaserCUSING manufactured Ti-6Al-4V remain. First, the pores and micro-flaws serve as stress raisers, and have been shown to reduce drastically the fatigue life in the high cycle fatigue regime by about a hundred-fold [17]. Unless pore sizes are minimised through a HIP process, the as-built material will not be accepted for aerospace applications. Furthermore, concern exists about the inability of heat treatments to produce percentage elongation values close to those of the conventional material. This is because complete conversion from the martensitic microstructure to a biphasic $\alpha+B$ structure is required [15]. Further mechanical testing is required to identify an appropriate heat treatment for the improvement of this property.

\section{CONCLUSION}

The purpose of the presented work was to characterise the material behaviour of LaserCUSING produced Ti-6Al-4V ELI. This included an analysis of its hardness and density. The morphology of the microstructure due to various heat treatments, and the resulting influence on hardness, was also studied. The main findings lead to the following conclusions:

- $\quad$ LaserCUSING produced Ti-6Al-4V ELI is characterised by comparable hardness when subjected to appropriate heat treatments. The most appropriate treatment involves sub-transus annealing, and adapts the undesirable martensitic a' microstructure of the as-built condition into a biphasic form with a better balance between mechanical properties.

- Near-full density results are achieved through careful manipulation of scanning parameters. Although the remelt hatch pattern improves the average density across 
spacing-speed pairs, the highest density was obtained for the single layer pattern when fast scan speeds were complemented with narrow hatch spaces.

\section{ACKNOWLEDGEMENTS}

The authors express great appreciation to the staff of the Rapid Product Development Laboratory for the use of their LaserCUSING facilities, as well as to Dr Anton du Plessis and the Central Analytical Facilities for the X-ray CT scans.

\section{REFERENCES}

[1] Bourell, D.L. \& Beaman Jr., J.J. 2003. Chronology and current processes for freeform fabrication, Journal of the Japan Society of Powder and Powder Metallurgy, 50(11), pp 981-991.

[2] Hague, R.J.M., Campbell, R.I. \& Dickens, P.M. 2003. Implications on design of rapid manufacturing, Proceedings of the Institution of Mechanical Engineers, Part C: Journal of Mechanical Engineering Science, 217(1), pp 25-30.

[3] Bremen, S., Meiners, W. \& Diatlov, A. 2012. Selective laser melting: A manufacturing technology for the future?, Laser Technik Journal, 9(2), pp 33-38.

[4] Wehmöller, M., Warnke, P.H., Zilian, C. \& Eufinger, H. 2005. Implant design and production: A new approach by selective laser melting, International Congress Series, 1281, pp 690-695.

[5] Yang, Y., Su, X., Wang, D. \& Chen, Y. 2011. Rapid fabrication of metallic mechanism joints by selective laser melting, Proceedings of the Institution of Mechanical Engineers, Part B: Journal of Engineering Manufacture, 225(12), pp 2249-2256.

[6] Guo, N. \& Leu, M.C. 2013. Additive manufacturing: Technology, applications and research needs, Frontiers of Mechanical Engineering, 8(3), pp 215-243.

[7] Scheifenbaum, H., Diatlov, A., Hinke, C., Bültmann, J. \& Voswinckel, H. 2011. Direct photonic production: Towards high speed additive manufacturing of individualized goods, Production Engineering - Research and Development, 5(4), pp 359-371.

[8] CONCEPT Laser GmbH. 2010. M2 Cusing Operation Manual: Powder Container Version.

[9] Lütjering, G. \& Williams, J.C. 2007. Titanium, $2^{\text {nd }}$ edition, Springer Science \& Business Media, Heidelberg, Germany.

[10] Donachie, M.J. 2000. Titanium: A technical guide, $2^{\text {nd }}$ edition, Materials Park, Ohio, ASM International.

[11] Beck, M.M. 2012. Customized knee implants: Evaluation and qualification of materials and new manufacturing processes, Technische Universität München, Germany, Diploma-Thesis.

[12] Knowles, C.R. 2012. Residual stress measurement and structural integrity evaluation of SLM Ti6 Al-4V, University of Cape Town, Cape Town, Master's Thesis Final Report.

[13] Knowles, C.R., Becker, T.H. \& Tait, R.B. 2012. The effect of heat treatment on the residual stress levels within direct metal laser sintered Ti-6Al-4V as measured using the hole-drilling strain gauge method, Proceedings of the $13^{\text {th }}$ International RAPDASA Conference, Sun City.

[14] Kruth, J.P., Badrossamay, M., Yasa, E., Deckers, J., Thijs, L. \& Van Humbeeck, J. 2010. Part and material properties of selective laser melting of metals, Proceedings of the $16^{\text {th }}$ International Symposium on Electromachining.

[15] Facchini, L., Molinari, A., Höges, S. \& Wissenbach, K. 2010. Ductility of a Ti-6Al-4V alloy produced by selective laser melting of prealloyed powders, Rapid Prototyping Journal, 16(6), pp 450-459.

[16] Becker, T.H., Beck, M. \& Scheffer C. (in review). Microstructure and mechanical properties of direct metal laser sintered Ti-6AL-4V, South African Journal of Industrial Engineering.

[17] Leuders, S., Thöne, M., Riemer, A., Niendorf, T., Tröster, T., Richard, H.A. \& Maier, H.J. 2013. On the mechanical behaviour of titanium alloy TiAl6V4 manufactured by selective laser melting: Fatigue resistance and crack growth performance, International Journal of Fatigue, 48, pp 300-307.

[18] Thijs, L., Verhaeghe, F., Craeghs, T., Van Humbeeck, J. \& Kruth, J.P. 2010. A study of the microstructural evolution during selective laser melting of Ti-6Al-4V, Acta Materialia, 58(9), pp 3303-3312.

[19] Kuhlman, G.W. in: Kim, Y.W. \& Boyer, R.R. (eds). 1991. Microstructure/property relationships in titanium aluminides and alloys, TMS Publications.

[20] Vracken, B., Thijs, L., Kruth, J.P. \& Van Humbeeck, J. 2012. Heat treatment of Ti-6Al-4V produced by selective laser melting: Microstructure and mechanical properties, Journal of Alloys and Compounds, 541, pp 177-185.

[21] Van Rooyen, M. 2013. Material characterisation of LaserCUSING manufactured Ti-6Al-4V - Part I, University of Stellenbosch, Stellenbosch, BEng Final Year Project Report.

[22] Khan, M.R. 2014. Microstructural investigation of selective laser melted Ti-6Al-4V, University of Stellenbosch, Stellenbosch, BEng Final Year Project Report. 
[23] Lampman, S. 1990. Properties and selection: Nonferrous alloys and special-purpose materials: Wrought titanium and titanium alloys, ASM International, 2(10), pp 592-633.

[24] Yadroitsev, I. \& Smurov, I. 2011. Surface morphology in selective laser melting of metal powders, Physics Procedia, 12, pp 264-270.

[25] Yadroitsev, I., Bertrand, Ph. \& Smurov, I. 2007. Parametric analysis of the selective laser melting process, Applied Surface Science, 253(19), pp 8064-8069.

[26] Yasa, E. \& Kruth, J.P. 2011. Microstructural investigation of selective laser melting 316L stainless steel parts exposed to laser re-melting, Procedia Engineering, 19, pp 389-395.

[27] Vilane, V. 2013. Grain refinement in cast titanium 6-aluminium 4-vanadium by hydrogenation, deformation and recrystallisation, University of Cape Town, Cape Town, Master's Thesis Final Report.

[28] Yasa, E. \& Kruth, J.P. 2011. Application of laser re-melting on selective laser melting parts. Advances in Production Engineering \& Management Journal, 4(4), pp 259-270. 